\title{
New audience dimensions in streaming platforms: the second life of Money heist on Netflix as a case study
}

\author{
Elena Neira; Judith Clares-Gavilán; Jordi Sánchez-Navarro
}

Nota: Este artículo se puede leer en español en:

http://www.profesionaldelainformacion.com/contenidos/2021/ene/neira-clares-sanchez_es.pdf

How to cite this article:

Neira, Elena; Clares-Gavilán, Judith; Sánchez-Navarro, Jordi (2021). “New audience dimensions in streaming platforms: the second life of Money heist on Netflix as a case study". Profesional de la información, v. 30, n. 1, e300113.

https://doi.org/10.3145/epi.2021.ene.13

Manuscript received on May $27^{\text {th }} 2020$ Accepted on September $23^{\text {rd }} 2020$

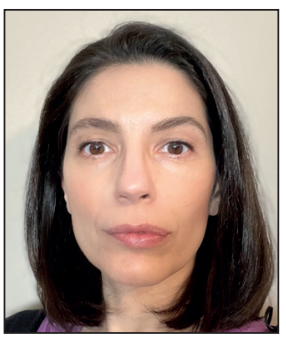

Elena Neira $\bowtie$ https://orcid.org/0000-0002-8565-2889

Universitat Oberta de Catalunya Estudios de Ciencias de la Información y de la Comunicación Av. Tibidabo, 39-43 08035 Barcelona, Spain elena@laotrapantalla.com

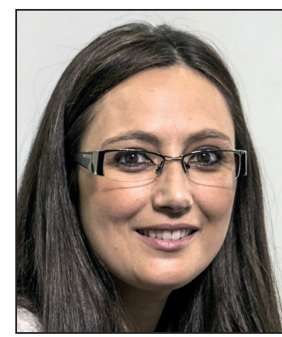
Judith Clares-Gavilán https://orcid.org/0000-0002-7462-9712

Universitat Oberta de Catalunya Estudios de Ciencias de la Información y de la Comunicación Av. Tibidabo, 39-43 08035 Barcelona, Spain jclares@uoc.edu

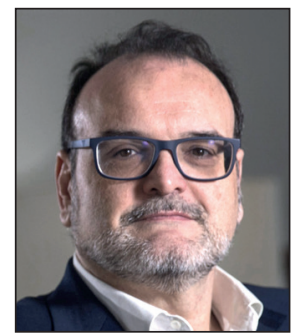
Jordi Sánchez-Navarro
https://orcid.org/0000-0002-0311-1385
Universitat Oberta de Catalunya
Estudios de Ciencias de la Información y de
la Comunicación
Av. Tibidabo, 39-43
08035 Barcelona, Spain
jsancheznav@uoc.edu

\begin{abstract}
The growth in popularity of on-demand content consumption, boosted by large global agents such as Netflix, Amazon and $H B O$, has brought audience fragmentation even further. Exponential growth in the content available to users (which reduces viewer concentration based on a limited selection), its commercialisation through a subscription-based business model (removing advertising from content) and the boom in consumption on different receivers, many of them mobile or outside the home (thus complicating people meter monitoring), has generated a new ecosystem where success can no longer be assessed using traditional audience measurement systems. This article discusses audience behaviour in streaming platforms and the new dimensions used to measure the success of a television series, above and beyond data provided by television audience measurement (TAM) techniques. From this analysis, the article reviews the transformation in the concept of popularity and how new audience indicators affect the structure of the content distribution medium, which adds further dimensions (engagement, customer retention, talent acquisition, new subscriptions and branding, among others) to more traditional elements (advertisers and international sales). Finally, we examine whether a single concept of audience, valid for all consumption models and audiovisual operations, can be established. Money heist is used as a case study, as it provides a good example of two ways of understanding audience: one linked to its commercial success in the Antena 3 Televisión channel's scheduled programming and the other arising from its inclusion on Netflix, the platform that gave it worldwide popularity.
\end{abstract}

\section{Keywords}

Audiences; Netflix; Antena 3; Popularity; Money heist; Success; Big data; Demand expressions; Audience measurement; Rating; Share; TAM; SVOD; VOD; OTT; On demand. 


\section{Introduction}

Good knowledge of the target public for an economic activity is an essential aspect for all businesses. Without knowledge of audiences, users or customers, it would be impossible to satisfy their demands, forge a good market position or develop profitable services (Portilla; Vara-Miguel; Díaz-Espina, 2016). This media interest in audience is an important aspect in the logic of commercial television, which for a long time has operated with a simple dynamic: making content profitable based on the number of viewers it is able to attract (Clares-Gavilán; Merino-Álvarez; Neira, 2019). If audience has been the main financial motor for television, then advertising has been its main nourishment (Vacas, 2012).

Audience research is essential for obtaining information on the public's behavioural habits, likes, preferences and needs (Iglesias, 1985). Furthermore, audience measurement is a key element for diagnosis, forecast and planning (with the aim of quantifying reception for content within programming schedules, forecasting potential audience for similar programmes and deciding whether they should be kept in the schedules). In the commercial channel ecosystem, techniques for television audience measurement (hereinafter referred to as TAM) have on the whole become rating tools, as the value of a time band is based on viewer numbers concentrated around the broadcast (De-Durán, 2014). This commercial interest, which considers audience attention as goods (McQuail, 1992), establishes a direct relationship between channel and advertiser, in which viewers are the currency whereby the price of advertising space is calculated.

As Jauset explains,

"it is essential to know audience levels for each space or programme on a television channel, as they have a direct impact on the main source of income, i.e. selling spaces or time bands, whose price varies with the audience level" (Jauset, 2014).

The first decade of the 21st century saw the development of a new audiovisual system, in which the Internet played a central role (Corbella, 2010). From the start, television via this new broadcasting technology was seen as the driver for future growth in the audiovisual market, although it has eroded classic, mainly advertising-based business (Arrojo, 2010; Álvarez-Monzoncillo, 2011). This digital transition brought with it new complexities, especially in terms of audiences, which professionals in the sector now consider to have reached a low point, as they are considered insufficient for the emerging communicative environment (González-Neira; Quintas-Froufe; Gallardo-Camacho, 2020). According to recent research, two of the biggest challenges facing TAMs are, firstly, the problem of approaching audiences that are elusive and invisible with regard to the screen docking system and, secondly, the rapid obsolescence of strategic innovations due to the speed of progress in digital culture (García-Santamaría; Barranquero-Carretero; Rosique-Cedillo, 2017; Huertas, 2018; Núñez-Ladevéze; Torrecillas-Lacave; Irisarri-Núñez, 2019).

The growth in popularity of streaming and on-demand content consumption, boosted by large global agents such as Netflix, Amazon and $H B O$, has produced significant disruption in consumption habits and further heightened the phenomenon of audience fragmentation, marking the switch from paleotelevision to neotelevision (Vacas, 2012). As well as these new operators, the appearance of new packages and types of data has had a significant impact on companies operating in the context of TAMs (Portilla, 2015; Callejo-Gallego, 2019). Exponential growth in content available to users (reducing viewer concentration on a limited selection), its commercialisation through a subscription-based business model (removing advertising value from the content) and the boom in consumption outside broadcasting times on different receivers, many of them mobile or outside the home (thus complicating monitoring with people meters) has generated a new ecosystem where success can no longer be assessed exclusively using traditional audience measurement systems. Media audiences are now defined as atawad, an acronym of 'any time', 'anywhere' and 'any device'. Indeed, the term has been extended to atawad+ac, adding 'any content' to the formula, Hernández-Pérez; Rodríguez-Mateos, 2016). The consolidation of this new type of viewer has disrupted analogue model-based business (Álvarez-Monzoncillo, 2011). It has also laid bare the need to rethink the utility and quality of measurements, even generating a specialist field of measurement studies (Huertas, 2018).

What we term audience is today a reality made up of vast amounts of data characterised mainly by its fragmentation. Data is taken from a wide range of sources and its relationship with real consumption is not always clear, leading to multiple interpretations (Hernández-Pérez; Rodríguez-Mateos, 2016). This environment of global, decentralised, on-demand viewing has also brought about a redefinition of the concept of popularity. In the context of streaming in the subscription video-on-demand (SVOD) model, where the release of audience figures is not standard practice, how can one know if a programme is a success? This situation is particularly striking in the case of platforms' leading series, or tentpoles (Neira, 2020), which are the main hook for attracting new customers. Such programmes can provide the focus for a large volume of different interest expressions (social conversation, Internet searches, shared content and illegal downloads, among others) that express a desire for, or interest in, consumption, thereby demonstrating the powerful impact of the content, feeding users' interest in being (or continuing to be) a platform customer. These demand expressions (using the term coined by Parrot Analytics), which circulate outside the TAMs, take on special relevance in the SVOD business model, which limits the audience's value

Today, audience is a reality consisting of vast amounts of data characterised mainly by its fragmentation; thus its relation to real consumption is not always clear 
as goods for the advertising industry while raising its value as platform customers (McQuail, 1992; Álvarez-Monzoncillo, 2011; De-Durán, 2014).

Money heist (original title: La casa de papel) provides an appropriate case study to assess the concept of programme success and popularity, as it allows us to analyse its performance on two different distribution channels: a national commercial television channel (Antena 3) and a global streaming platform (Netflix). Since its inclusion in the Netflix catalogue, Money heist has frequently been described as a phenomenon. However, this phenomenon is unquantifiable as there is no audited audience data for the series on the platform.

\section{Objectives and methodology}

The main objective of this article is to progress toward a new concept of audience in the context of on-demand video consumption in the subscription model (taking Netflix as a reference, given its market importance) and reflect on whether a single concept of audience can be applied to all on-demand audiovisual consumption and business models. To do this, the following research questions (RQ) are posed:

RQ1: How do audiences on streaming platforms behave? By extension, this question involves examining how audience is quantified and/or weighted and whether, in this context, we can continue to consider audience as goods.

RQ2: What aspects should a new, revised concept of audience consider in the context of SVOD? What new audience dimensions does the concept of video consumption on streaming platforms introduce?

RQ3: Do new audience dimensions require a new concept of popularity?

RQ4: Can a single concept of audience be applied to all on-demand audiovisual consumption and business models?

The series Money Height, created by Àlex Pina, provides an appropriate case study for assessing the concept of programme popularity in relation to two different distribution channels:

- a national commercial television channel (the series was first scheduled on Antena 3, with relative success) and

- a global streaming platform (where it became the most-viewed fiction series in Spanish in the platform's history).

As no audience figures are available, evidence for this success is based on company statements (unaudited) and its viral behaviour, boosted by a new digital audience, which seeded interest in the programme, attracting new mass audiences and customers to the service, seduced by its impact.

To answer these research questions and thus achieve the objective of this article, we will analyse the following issues:

-the crises of the TAMs;

- new television measurement formulas;

- new forms of measurement incorporated into online video platforms;

- new audience dimensions; the new concept of success and popularity;

- audience behaviours in the context of streaming platforms;

- the way Netflix conceptualises and measures the audience for their programmes;

- the specific analysis of the commercial life of Money heist.

This study takes as its framework the academic and professional research on audiovisual visual distribution in the online environment in general and on Netflix in particular (Keating, 2012; Tryon, 2013; Cunningham; Silver, 2013; Holt; Sanson, 2013; Curtin; Holt; Sanson, 2014; Lotz, 2014; 2018; Landau, 2016; Lobato, 2019). It also uses on audience research, in particular that which focuses on basic aspects such as methodology, development and purpose within the media ecosystem (Iglesias, 1985; McQuail, 1992; Huertas, 2002; Morley, 2003; Gillespie, 2005; Napoli, 2008; Jauset, 2014; Castillo-Izquierdo, 2016).

A wide-ranging review of the literature on other aspects, such as the impact of digitalisation on the audiovisual market in terms of cultural homogenisation and defending diversity (Clares-Gavilán, 2014; Albornoz; Leiva, 2017; Clares-Gavilán; Medina-Cambrón, 2018) and the transformation of viewing habits, was also conducted. The latter field has led to new lines of research that propose new approaches to audience measurement, such as those focussing on:

- online-offline convergence (Callejo-Gallego, 2002; Webster, 2014; Portilla, 2015; Rodríguez-Mateos; Hernández-Pérez, 2015);

- the social audience (Gallego, 2013; Quintas-Froufe; González-Neira, 2016; Halpern; Quintas-Froufe; Fernández-Medina, 2016; Núñez-Ladevéze; Torrecillas-Lacave; Irisarri-Núñez, 2019; Masip; Ruiz-Caballero; Suau, 2019; Vázquez-Herrero; González-Neira; Quintas-Froufe, 2019; González-Neira; Quintas-Froufe, 2020);

- big data (Fernández-Manzano; Neira; Clares-Gavilán, 2016; Napoli, 2016; Smith; Telang, 2016).

We consider the case study (Yin, 2009) to be the most appropriate methodology to use here, as this is an empirical analysis with numerous knowledge sources for researching a modern phenomenon. Hence, we use primary and secondary sources related to our field of analysis (programme audience and popularity): literature review, data provided by the audience measurement company in Spain, statements from Netflix employees (in professional forums that provide public records), data released by Netflix (from its press office, on its Netflix Research website and in letters to shareholders attached to quarterly financial statements) (Netflix Investors, 2018; 2020a; 2020b), and analyses in the trade press. 
The methodological analysis is complemented by three in-depth interviews. The Atresmedia Televisión director of digital content and social media, Francisco Sierra Hernando, and the former director of product design and business development for Atresmedia Digital, Jesús Moreno, helped provide an idea of the digital popularity of Money heist before its inclusion in the Netflix catalogue and the impact of the series' success on the Antena 3 brand. Also interviewed for this article were Alejandro J. Rojas, director of applied analytics at Parrot Analytics, the company that has developed its own analysis system for researching popularity in digital content distribution environments. Parrot Analytics provided ad hoc information for this study, which helped follow the changes in Money heist's popularity after its inclusion in the Netflix catalogue.

\section{The crises of the TAMs}

As a means of promoting market transparency, television channels agreed to undergo a single, external, independent audit to measure audience figures for their scheduled programming and their share of total television consumption. The aim was to ensure users of these audience figures (the television and advertising industries) did not receive contradictory data when signing sales agreements. They all accepted the survey methodology with regard to sample selection, data collection and the final indicators (Huertas, 2002).

The current TAM system, which in Spain follows the tradition of a single study per country (Huertas, 2006), is based on data provided by a people meter, a device installed in the homes of a representative sample of the Spanish population (residents aged over 4 in first and second homes with a television set), which counts each person, identified by remote control, as a member of the audience after detecting them watching a programme for several consecutive seconds. In Spain, the reference unit is the minute, i.e. the programme or channel selected for the most seconds in a given minute is considered to have received the audience. Given that the audience varies from minute to minute, the mean audience indicator is used when referring to a programme's audience, i.e.

"the number of individuals who maintain contact with the televised medium over a period of time, bearing in mind the duration and counting repetitions in each minute" (Jauset, 2014).

Thus the audience is calculated by adding up the total audience for each programme minute and dividing the resulting figure by the number of minutes the programme lasts.

Although the people meter technique is far from perfect, it has provided stability to the industry for some years. It is ideal in a context of controlled supply where the type of consumption is relatively uniform, as it was when watching television was the main leisure activity in Spanish homes.

Since 1993, when the merger of Ecotel and Media Control gave rise to Sofres Audiencia de Medios (who introduced the current TAMs), viewers' habits, on which each channel's audience rating and share are constructed, have changed considerably. This complexity in the audiovisual market is the result of the digital transition. Along with steady audience fragmentation and the rise in converging processes, there has been a growth in pay television and economic threats from new forms of Internet consumption (García-Santamaría; Barranquero-Carretero; Rosique-Cedillo, 2017). The vast range of viewing combinations has raised numerous questions (Hernández-Pérez; Rodríguez-Mateos, 2016). Thus new types of audience have arisen.

According to the analysis contained in Análisis televisivo 2019 by the consultancy firm Barlovento Comunicación, in that year average daily television consumption was 222 minutes per person per day in a 'consumption universe' of 45,071,000 people in Spain aged 4 or over, 12 minutes less than in 2018 . These 222 minutes per person per day can be broken down into three categories for classifying television viewing:

- linear (206 minutes);

- delayed (watching a programme up to seven days after its original broadcast); and

- invited (people not included in the panel but who have been added to it at some time).

The concept of delayed audience (watching television content after its original broadcast) has brought about rapid and unprecedented sociological change, highlighting one of the weaknesses in TAMs. With the proliferation of leisure options, individuals' attention is no longer as focused as before and is spread over an increasingly broad offer. Not only do we watch less television (one has to go back to the 1990s for figures similar to 2019), but we also watch conventional television differently. Habits among television viewers, especially younger viewers, are being infected by these new forms of on-demand and destructured consumption, as shown by increasing use of à la carte television services to the detriment of scheduled broadcasts. Equally relevant is the phenomenon of social television, the result of adding social media to the television experience, resulting in an online space that increases interactivity in shared programming (Halpern; Quintas-Froufe; Fernández-Medina, 2016). Constant demands to consider the social audience as a complement to linear audience data is justified by its consolidation, thanks to acceptance by the public and its increasing use by television channels (Quintas-Froufe; González-Neira, 2016).

The disruption to standardised consumption, the basis for traditional TAMs, is based on a new configuration in responses and attitudes among audiences (Roncallo-Dow, 2016), who now see choosing how, where, and when to watch as an inalienable right (Neira, 2015). An empowered audience such as this introduces a number of subjective variables in the 
context of new relationships established between a less passive viewer and the so-called new media. The larger offer (which has lowered the figures for audiences concentrated on a small number of programmes), its operating model (subscription without advertising) and the rise in signal reception devices, leading to increased mobile viewing (beyond the range of people meter monitoring), have produced a new model that combines infinite consumption that is difficult to parameterise. As Callejo-Gallego (2019) notes, what we are seeing is an audience that has not yet been produced by measuring instruments or which still lacks the instruments for its comprehensive measurement.

We now no longer talk only about cultural and commercial television. The business side of the new television, provided directly to consumers and based on monthly subscriptions (SVOD), is transformed: viewers have become customers of a personalised offer. As predicted by Huertas,

"although it has become normal since the end of the 20th century to treat the audience as customers or users, in the future this term will become ever more widespread. Whereas traditional television spoke with a single message directed to the crowd (citizens or consumers), who did not share the same space, television of the future is shaping up to be in the form of service or experience distribution companies aimed at meeting individuals' (customers') needs" (Huertas, 2002).

Consumption of streaming content adds new dimensions not only to the traditional audience concept but also to the concept of programme success. Given that viewing concentrated on a specific space and time is no longer the default option and multi-speed consumption has become the new normal, the need arises to develop different indicators of programme success, as discussed below.

\section{New formulas for television measurement}

Technological changes have transformed production, diffusion and consumption practices, making this a crucial moment in audience research (Cascajosa-Virino, 2016). Consequently, traditional television is experiencing hard times. As TAMs are based on concentration and market share and calculated using people meters, their blind spots have been highlighted by the growing number of operators in the audiovisual entertainment sector. The emerging streaming culture has had a clear impact on traditional media, most noticeably the drop in linear viewing numbers. Public and private channels responded to this phenomenon with à la carte television services, in which programmes can be watched after their original broadcast times and on devices other than the television set. They decided to offer this alternative, which more closely matched the new forms of audiovisual consumption, to adapt to these new consumption habits. And they did so knowing what the collateral effect would be: loss of linear television audiences to on-demand services, which are more convenient for users but much less profitable, in terms of advertising, for television channels. The delayed and disseminated audience has been included in Kantar Media measurements to provide a more complete picture of current consumption, which clearly shows there is no longer a single audience, but many different ones, on different media and with very different consumption times (Rodríguez-Mateos; Hernández-Pérez, 2015). The solution involves broadening data collection with guaranteed (i.e. audited), hybrid, cross-media systems (Portilla; Vara-Miguel; Díaz-Espina, 2016; Huertas, 2018).

European practice is described in the study by Papí-Gálvez and Perlado-Lamo-de-Espinosa (2018) on audience research in digital societies, based on an analysis of 23 countries. In Europe the techniques of

- audiomatching: the people meter takes video and/or audio samples from the channels being watched or listened to by the panel member and compares them to the original broadcast signal;

- fingerprinting: the device extracts the audio 'digital fingerprint' captured from the television broadcast and compares it to a centralised fingerprint database.

These techniques recognise the audio or video being viewed (either live or delayed) and associate it with the corresponding programme. The range established to define the delayed audience (i.e. number of days after the initial broadcast to consider it as having been viewed) is the vosdal (viewing on same day as live), which may be extended to the following seven days (+7). Kantar Media has adopted this model, terming it time shift. As Gallardo-Camacho, Sierra-Sánchez and Lavín (2019) explain, people meters count the non-linear audience on the same day of broadcast up to 2:30 am (vosdal) and on the next seven days $(+1,+2,+3,+4,+5,+6$ and +7$)$. The delayed audience is also counted in two sites at once:

- in the delayed audience in viewing time (DAV) and

- in the delayed audience in broadcast time (DAB).

DAV refers to the exact time delayed content is consumed and DAB is added to the delayed audience for the original broadcast programme.

Thus, the new system enables previously broadcast content to be viewed up to seven days later and included in published audience figures, as long as the programme is viewed in the home (on a television set or connected computer).

This solution included in TAMs shows how corrections to audience deviation are being made while maintaining the panel methodology (a representative sample of the Spanish population) in a mass consumption environment marked by inertia in television viewing. In other words, views are accumulated over seven days, based on the pattern of weekly consumption, which is also the basis for catch-up services (on-demand services mean a programme can be watched if originally missed in linear viewing, always with the aim of prioritising the scheduled television experience). 
The much sought-after comprehensive disseminated audience measurement, which includes other devices, was given a definitive boost by the agreement between Kantar Media and Comscore (the company responsible for online measurement in Spain), using a method based on unified digital measurement. This merged television in all platforms (regardless of broadcast time and consumption device) and the online audience, so that each individual in the television panel also has their online viewing included (Quintas-Froufe; González-Neira, 2016). However, this new, complete, hybrid and non-duplicated measurement solution is only available to customers who decide to contract it.

\section{Measurement formulas in online video platforms}

Despite the specific weight of streaming platforms in the subscription model of the audiovisual market and the resulting need to compare their consumption with traditional television, the activity of the former services falls outside the conventional measurement system (González-Neira; Quintas-Froufe; Gallardo-Camacho, 2020). Their business model (based on monthly subscriptions, not advertising), the type of consumption generated by a lack of programme scheduling (destructured and at differing speeds) and the differing degrees to which these services are adopted in the home (compared to statistics on television penetration, which is around $100 \%$ of the population) means it is not only difficult to apply the main TAM indicators but also there is little desire to share information.

The case of Netflix is an excellent example. The company operates without having to share details on how well its programmes are doing. As it does not use advertising, it has no need to negotiate with advertisers or agencies. In addition, its economic model in relation to creators and rights owners is not based on royalty payments per play (except in the case of original productions in some EU countries with specific viewing quotas: over 10 million accounts that have completed $90 \%$ of an original production of the platform), but on paid-up licences, whereby a variable amount is paid, depending on how long the platform streaming licence lasts. If one also considers that they have their own mechanisms for identifying customers' consumption habits, there appears to be little incentive to develop shared, public surveys (Huertas, 2018).

A comparison of services and programmes on equal terms is relatively simple in the case of television. A television audience measurement system could be implemented because the channels agreed to accept external auditing and the methodology used. However, streaming platforms have shown no interest in being subject to independent control that would provide customers (production companies and creators) and the market with certain types of information. Quite the opposite. Apart from occasional promotional headlines accompanied by figures on how well its programmes are performing, 'non-audience' has become a habitual practice.

Hence the question is whether an audience measurement system can be defined and standardised for SVOD. Audiences today are diffuse but at the same time connected to the daily events (Masip; Ruiz-Caballero; Suau, 2019). This is described in Callejo-Gallego (2019) as a gaseous audience, one that arises in different places that are difficult to measure and register. And it is the volatility of this audience that makes users' adherence to content and the quality of this connection so important, in a dynamic that differs from traditional television consumption, instead resembling digital consumption. Interesting conclusions may be drawn by analysing the types of consumption and measurement associated with other online video distribution channels, such as YouTube, Facebook, Instagram and Twitter. Although the purpose of almost all metrics is to monetise advertising (which SVOD does not have), its consumer-centric approach is an interesting one. Elements used to 'assess' users' relationship with content include repeated use, intensity and the frequency of this relationship with the content-providing platform. As with television, the online environment has a basic quantitative metric: views (Image 1). Indeed, total cumulative views is the most frequently demanded indicator for SVOD platforms, as this is a real metric (not

\section{HOW PLATFORMS ACCOUNT AUDIENCE MINIMUM TIME REQUIRED TO REGISTER 1 VIEW ON EACH PLATFORM}

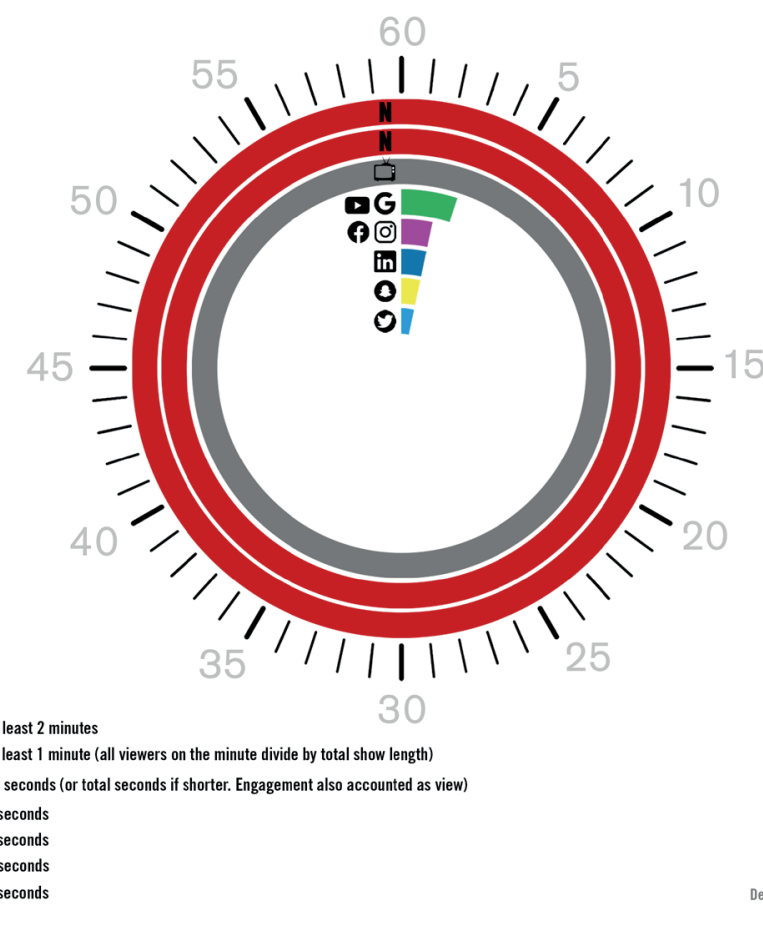

Design: Teresa Farell

Image 1. How platforms account audience 
a panel-based estimate), which is easy to extract and simple to understand. Furthermore, views are an easier way of isolating the voluntary act of wanting to watch a video (on demand) in a concept similar to appointment $T V$, where programmes are not watched as part of a programme schedule but specifically sought, thereby requiring a degree of commitment (DeFino, 2013). But the relationship of the audience to content may involve much more than just viewing. In a multidimensional model, such as the one analysed here, audience behaviour switches between different states which go beyond mere impact, such as reputation, interest, coverage and memory (Napoli, 2012).
Engagement enriches mere views in the case of unstructured consumption. But there remains a clear problem with integrating diverse forms of consumption, processing data and assigning values to each subjective audience attitude. Reaching a consensus on this weighting still poses a major hurdle

Given the anarchical, destructured nature of consumption on a streaming platform with a large catalogue, cumulative figures pose an additional problem: establishing a relevant time range (such as the 7-day time shift, based on the logic of weekly broadcasts). Views are also a somewhat superficial measure when the medium gives the user 'power' in controlling content broadcasting. Simple continuity of play and interaction quality are significant in terms of users' commitment to the platform, which is a cornerstone in these services, as discussed below.

\section{New audience dimensions}

How can the picture of consumption in the online environment be completed? As shown by the analytics channels provided for content creators and advertisers in the digital environment, cumulative views are complemented by new dimensions, more subjective metrics, such as average view duration, video percentage watched, audience retention and watch time. These variables aim to assess the degree of commitment not only to the video but also to the platform providing it, a concept (one of different degrees of attention, such as adhesion and commitment) whose importance was highlighted by McQuail (1992).

Recent academic literature includes an increasing number of references to these new audience dimensions, especially engagement, which is derived from the previous concept and highlights the direct relationship between users and content. However, there is still no consensus on the matter. Some authors associate it with online conversations that boost content liked by the audience (the basis of the social television phenomenon), while others highlight the user's close, committed relationship with the programme in question (Huertas, 2018). Whatever the case, all approaches agree that engagement enriches mere views in the case of unstructured consumption. But there remains a clear problem with integrating diverse forms of consumption, processing data and assigning values to each subjective audience attitude. Reaching a consensus on this weighting still poses a major hurdle.

\section{Success and popularity for audiovisual content in the on-demand environment}

The concept of success for audiovisual content is traditionally associated with its popularity which, according to the dictionary definition, means achieving fame and respect. Programme popularity is highly conditioned by the distribution channel. For commercial and pay channels, for instance, success is understood in terms of earnings, but in a different way to commercial channels, where programme acceptance (in terms of good audience figures) means the space can be profitable for advertising. In the case of pay television, whose main concern is ensuring minimal churn (i.e. number of customers leaving), acceptance of their offer creates customer loyalty and attracts new subscribers. The greater the customer retention and numbers of new subscribers, the greater the profit for the company. SVOD platforms share the latter concept of programme popularity since it matches their strategic business goal: attracting and retaining subscribers, creating loyalty to the service and obtaining good general product satisfaction rates (Gómez-Uribe; Hunt, 2015). Todd Yellin, Vice-President of Product Innovation, said on one occasion that Netflix measures programmes' success based on the happiness they provide, paraphrasing Marie Kondo and her popular message of keeping those things that provide joy: 'If people enjoy our content, if they're loving to come to Netflix, then we succeed' (Roettgers, 2019).

SVOD platforms seek programme popularity as a means of achieving their strategic business goal: attracting and retaining subscribers, creating loyalty to the service and obtaining good general product satisfaction rates

\section{Audience behaviour in the context of subscription model streaming platforms}

In SVOD platforms, with a monthly subscription payment, users access a full programme catalogue, all of which they can watch. But very popular programmes, the previously mentioned catalogue tentpoles, have a significant impact on attracting customers (Neira, 2020). As Ball explains,

"This means that tentpole content doesn't just drive acquisition revenue, it drives the efficiency (and fans) of all other content investments as well" (Ball, 2019). 
In other words, once users join the customer base, they are potentially exposed to other programmes that subsequently act as a hook in retaining them.

On-demand consumption invalidates the premise behind TAMs: collective, concentrated and synchronous consumption, structurally linked to scheduling (Callejo-Gallego, 2019). With streaming platforms, individual, disseminated and asynchronous consumption abounds, although paradoxically, as Huertas (2018) notes, this does not imply a decrease in continuous consumption. An exponential rise in viewing has been observed in platforms that release complete new seasons of series at once, producing uninterrupted 'binge' viewing sessions. SVOD has given rise to a new system of entertainment and a new type of audience. One might say this audience is no longer 'prime time' but 'my time': viewers who direct and manage their own audiovisual experience based on an abundant, disorganised offer. If we also bear in mind the market globalisation boosted by these operators, we might conclude that it is the source of global, homogeneous demand, which can be satisfied internationally by the same product (Arrojo, 2010; Clares-Gavilán, 2014; Pacheco-Pailahual, 2017; Clares-Gavilán; Medina-Cambrón, 2018; Neira; Clares-Gavilán; Sánchez-Navarro,

\section{SVOD has given rise to a new system of entertainment and a new type of au- dience. One might say this audience is no longer 'prime time' but 'my time'} 2020).

Once the ability to select becomes a personal decision, the adhered audience, as opposed to audience as dispersed mass (McQuail, 1992), drives consumption flows that are multiplied by a huge range of motivations. The current situation suggests that such 'mass audience entertainment' (Núñez-Ladevéze; Torrecillas-Lacave; Irisarri-Núñez, 2019) is directly linked to popularity. With linear television, popularity is the seed from which a programme's appeal grows, through the dynamics of scheduling (at a specific time and date) and a selected, controlled product. In the context of streaming, popularity has become a key element in gaining visibility, not just in relation to the competition but also to other content on the same platform. With so many programmes to choose from, above and beyond the boost provided by marketing campaigns, popularity (once again understood as fame and respect) generates interaction and conversations. This phenomenon affects audience behaviour, activating codes of behaviour in other users and leading to greater interest in the programmes or series (Gallego, 2013; Halpern; Quintas-Froufe; Fernández-Medina, 2016). In the context of Netflix, the case study analysed in this article, it is interesting to note how the company, in its letters to shareholders, uses the term 'density of viewing' to describe the phenomenon whereby a rise in a programme's reputation boosts views, which is undoubtedly beneficial to the company: greater visibility leads to more views, which in turn leads to greater retention and conversation, more conversation leads to greater popularity, and greater popularity to greater impact, which, in the end, is a potential lever to attract new customers.

The recent addition of programme popularity ranking by country to the Netflix platform is fully aligned with this philosophy (Image 2). As explained on their website, this is a content selection updated daily, which varies with users' viewing history. The list is drawn up from programmes watched for at least two minutes in the last 24 hours, following the methodology used by the platform to calculate views.

\section{How Netflix conceptualises and measures audiences}

The desire to maximise the intensity of audience attention is fully applicable to the Netflix culture and helps achieve a number of objectives. For Netflix, the popularity of a series or film is an important aspect for strengthening the brand (generating prestige for the platform). It is also important in ensuring content serves as leverage for new subscribers (attraction) and as a key element in its relationship with existing ones (retention). All major investment in content is expected to boost growth in subscribers and retain the loyalty of current ones. This is achieved particularly well by popular programmes. As Toonkel, Dotan and Shah (2019), explain, Netflix judges the value of each individual programme as its ability attract and retain customers, a concept the company terms the adjusted viewer rate. In fact, this is a weighted quantitative metric (number of views), as it gives greater weight to views by people watching the content 24 hours after subscribing to Netflix or after weeks of not connecting to the service (who were, therefore, at risk of cancelling). In general terms, the regular (already loyal) viewer is assigned a lower value. The resulting figure is matched to the programme production budget to provide a second metric, the so-called efficiency score, to determine how efficient the investment

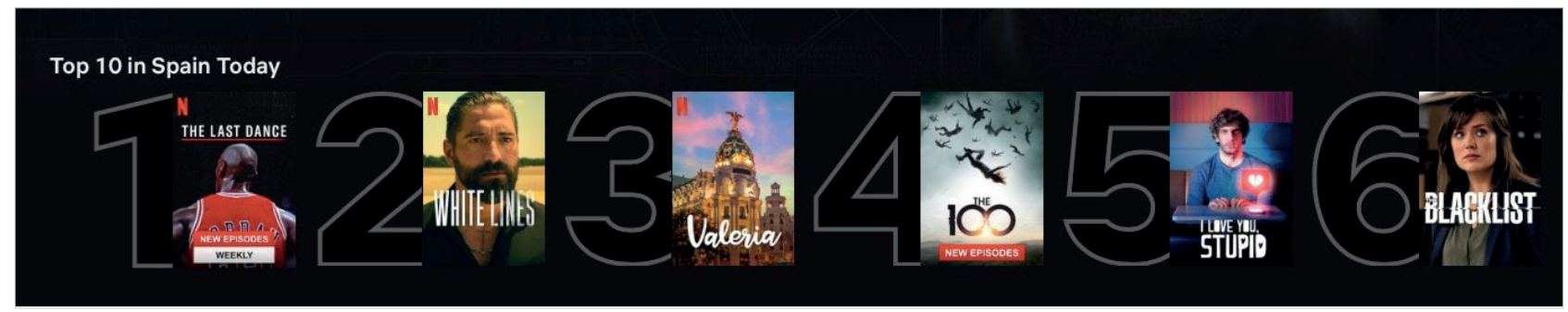

Image 2. Top 10 in Spain. Source: Netflix.com 
is in generating new subscribers. Programme popularity is relevant to the extent it attracts new customers to the platform or gets customers to use the service again after a long period of absence (reducing the likelihood of their leaving).

Netflix uses this constructed audience (Huertas, 2006) internally as an efficiency variable, where each view is weighted in terms of attraction and retention, taking into account the cost of the programme. As well as this internal audience, there is another external audience, more closely aligned to traditional TAM ratings, where the figures recorded for popular programmes are used as a publicity strategy. Recently, Netflix has been highly prolific in publicising its own audience figures, although they are not externally audited. The company's figures are global (not per country), associated with homes (accounts, not users linked to them) and cover a variable period (ranging from the release day to one month later). The parameters appear in a report presented by Netflix in July 2019 at the request of the British Parliament, as documentation for a session on public service broadcasting and video-on-demand operators. In the report, Netflix states that the company divides its users into three categories:

- completers: accounts that have watched $90 \%$ of a film or season;

- watchers: accounts that have seen $70 \%$ of a film or season;

- starters: accounts that have decided to watch at least two minutes of a film or season.

The first data to be published on its social media (on programmes such as Birdbox (Image 3), When they see us, Élite, You, La casa de las flores and The Irishman) referred to watchers.

However, there was a change in criteria with the release of The witcher in December 2019. Since then the figures it provides are for starters (accounts that have decided to watch at least two minutes of a film or series), a similar parameter to the audience base used for traditional television (one minute, although Netflix does not offer weighted figures) and the calculation used by the BBC for its iPlayer (explicitly referred to by the company in its Q4 2019 letter to shareholders).

\section{Money heist as a case study}

Money heist provides an appropriate case study for assessing the concept of programme popularity in relation to two different distribution channels: a national commercial television channel and a global streaming platform.

The series started as a production by Atresmedia and Vancouver Media, divided into two parts of nine and six episodes, respectively. It was released on Tuesday, 2 May 2017, on the Antena 3 channel, with an audience of 4,900,000 viewers and a $25.1 \%$ share. By the end of the season, in June that same year, the viewers and share had halved $(2,176,000$ viewers and $14.7 \%)$. There followed a four-month break in the broadcast, coinciding with the summer holidays, and the first episode of the second part was broadcast in October. Although prime-time audience figures for this episode exceeded the other two major channels, the figures continued to drop, while they remained stable for the series on its competitors' channels (Image 4).

The first digital run for Money heist was on Atresplayer, on the station's catch-up service. According to Atresmedia's director of product design and business development at the time, Jesús Moreno, the series averaged around 200,000 unique video users, a figure that not only remained stable but also rose slightly in the second season (up to 203,000 unique users) (Moreno, 2019; interviewed on 25/03/2019, authors' transcription and translation).
Netflix uses the term 'density of viewing' to describe the phenomenon whereby a programme's popularity boosts views, which is undoubtedly beneficial to the company: greater visibility leads to more views, which in turn leads to greater retention and conversation, more conversation leads to greater popularity, and greater popularity to greater impact, which acts as a lever to attract new customers 
Both seasons of Money heist were added to the Netflix catalogue (end of 2017 and April 2018), adjusting the episode length outside the domestic market to the service's regular format (40-50 minutes). Twelve days after the release of the second season, the company announced letter to shareholders (for Q1 2018) that Money heist was the most viewed non-English language series in the platform's history. This practice, offering viewing data relative to other programmes on the same service, is increasingly common in the streaming platform market (Cascajosa-Virino, 2018).

A month later, Netflix acquired the rights to the series to produce more seasons (Image 5).

This second online life for Money heist on a global streaming platform such as Netflix provided a clear boost to its popularity. As well as the rise in potential audience in other countries (Netflix is present in 190 countries), the series benefited from personalised recommendation algorithms, with proven effectiveness in boosting content discovery and consumption among user communities whose audiovisual preferences match the series (Fernández-Manzano; Neira; Clares-Gavilán, 2016). Furthermore, this data intelligence helps it forecast potential audiences for its series. Its Q1 2020 letter to shareholders explicitly refers to this point (Netflix Investors, 2020 b), as it predicted an audience of 69 million viewers for the first month of season four (recently released on the platform).

For Money heist, inclusion in the Netflix catalogue opened up new access formu-

las and helped strengthen consumption of the series, enhancing its reputation (Roel, 2019). In the online world at the current time, success of audiovisual content is accompanied by a large amount of information, large volumes of complex, heterogeneous data now the subject of analysis by companies looking to operate at mixers, with the aim of making sense of the information and make it useable for comparative purposes (Hernández-Pérez; Rodríguez-Mateos, 2016). In this context, the work of Parrot Analytics is particularly relevant. The company has developed its own analysis system to research content popularity on digital distribution environments, based on a conceptual framework that quantifies supply and demand in the global attention economy, using artificial intelligence technology to capture and process big data.

Their work is based on their own measurement unit termed demand expression. According to Alejandro J. Rojas, the company's director of applied analytics,

"previously, content offer was limited by TV channel programming times in a market. Today, the offer includes thousands of shows which television viewers can consume when they want, where they want, on multiple screens (television, mobile, computer, etc.) and platforms (free-to-air television, pay TV, OTTs). Given the abundant offer and diversity of access, traditional panel or sample-based demand measurement methodology loses its capacity to reflect audience behaviour globally. Today, television viewers interact actively with their favourite content, through discussions on social media, searching for and reading additional information online, viewing 


\section{Local demand as early signal of success}

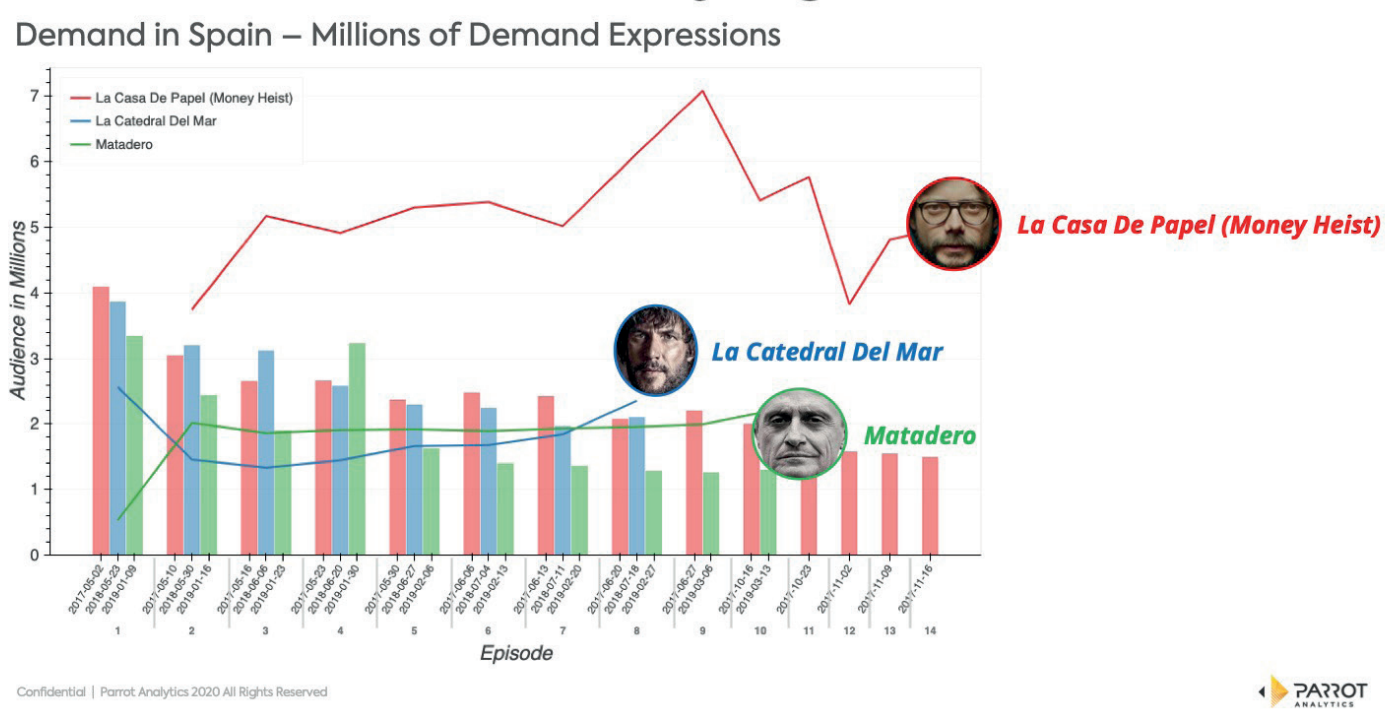

Image 6. Comparison of "demand expressions" of 3 series

online promotional videos and even illegal peer-to-peer downloading of episodes. All such online activities leave a digital footprint which is collected and processed daily by the Parrot Analytics infrastructure to generate the demand expressions produced by each programme" (Rojas, 2020; interviewed on 07/04/2020, authors' transcription and translation).

Demand expressions include all online activities associated with each programme using an algorithm that weights each activity according to the effort it requires. Effort is assessed in relation to its execution time, providing an end result that quantifies attention given by the public to each programme. The Parrot Analytics data on the Money heist case study offer interesting results. Firstly, they show similar behaviour in the ratings for different fictional content on the same platform. Money heist had higher ratings than other two cases taken to compare (Cathedral of the sea [original title: La catedral del mar] and Slaughterhouse [original title: Matadero]) on the Antena 3 schedule. But the impact of Àlex Pina's series was much higher even before its inclusion in the Netflix catalogue (Image 6). However, the increase in demand expressions was considerable once the series was added to the catalogue, both in Spain and internationally, while demand for the other two remained much more modest (Image 7).

\section{Demand after one year from release}

Cumulative Demand Abroad and in Spain - Billions of Demand Expressions

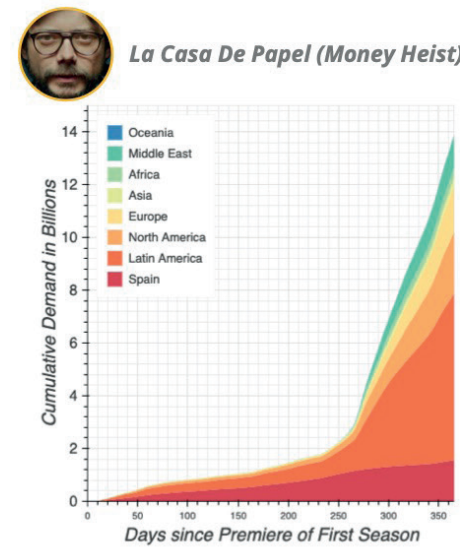

Confidential | Parrot Analytics 2020 All Rights Reserved

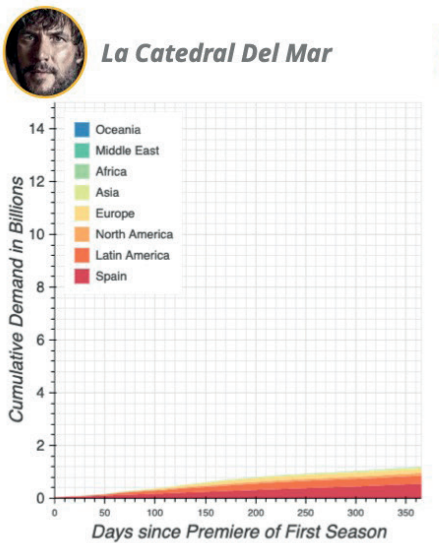

Days since Premiere of First Season

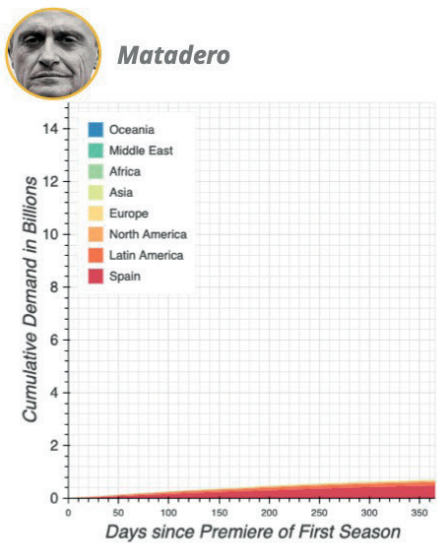

1 PARZOT

Image 7. Comparison of "expressions of demand" of 3 series after one year of their launch 
It is worth noting that this second life for series via on-demand video platforms, which has boosted the exportability of fiction internationally, clearly shows how important it is for television channels to establish a launch pad for their commercial cycle (Cascajosa-Virino, 2018). According to Francisco Sierra Hernando, director of digital content and social media at Atresmedia Televisión, the growth in demand for their series from SVOD platforms is because

"they realise that, independently of the audience for the free-to-air broadcast or on catch-up, we have been producing great series".

In April 2020, the 10 most widely consumed Netflix products included four by the Atresmedia brand:

- the fourth season of Money heist;

- Locked Up (original title: Vis a vis), whose spin-off El oasis was also in the top 10;

- the first season of Toy boy, another series to become an international hit, and which had recently been broadcast on Antena 3;

- and a fourth product, a film rather than a series, but also produced by Atresmedia Studios, The legacy of the bones (original title: El legado de los huesos).

In his opinion, this new product market clearly shows how release windows have changed. Toy boy is a good example:

"First it was released on Atresplayer Premium. Four weeks after the release of the first episode, it was broadcast on television. After it had been shown on the channel, all the VOD content was transferred to Netflix, where it quickly became one of the most viewed series in many countries".

Popularity, as an emerging element in weighting programme success, has led traditional operators to redesign their strategy. Sierra went on to say that

"the Money heist phenomenon led to the relaunch of many direct sales for other products and also accelerated the creation of an original content production division, Atresmedia Studios, where production is based on attention to quality criteria, fiction style, awareness of our public as a television channel, but targeting platforms such as Netflix, Amazon and Movistar" (Sierra, 2019; interviewed on 25/03/2019, authors' transcription and translation).

It also boosted Atresmedia's own platform, Atresplayer.

In fact, television channels no longer use TAMs as the sole metric for success. In the case of series, as noted by Jesús Moreno,

"the only valid metric at the end of the day is the profitability of the series; in other words, how much profit the series makes over its life cycle. And this life cycle starts with the television broadcast, and then continues with its marketing in advertising VOD and on subscription VOD, with sales to SVOD platforms such as Netflix, Amazon and $H B O$ and with international sales..., all of which is part of the success of a series" (Moreno, 2019; interviewed on 25/03/2019, authors' transcription and translation).

After its inclusion in the Netflix catalogue, the success of Money heist can be understood in a number of ways. As third-party content, its efficiency was more closely aligned to the number of viewing hours it was able to generate, increasing its value in terms of customer retention. Its rise in popularity and the second phase of its life cycle, as Netflix original content, increased its value as a tool for attracting new subscribers. This hypothesis is backed up by the company's carefully planned release strategy: aiming to concentrate viewing in its first few days on the platform, with social media communication dynamics that have redefined the concept of social television. It is no longer a collective conversation taking place simultaneously with the broadcast (an experience which the platform has disrupted with its viewing dynamics), but a community that feeds the feeling of belonging, where conversation raises interest in the programme and helps its spread, via the official social media accounts of Netflix, the series itself and its leading actors (Neira, 2020).

\section{Conclusions}

The main objective of this article is to help progress toward a new concept of audience in the context of on-demand video consumption in the subscription model (taking Netflix as a reference, given its market importance) and reflect on whether a single concept of audience can be applied to all on-demand audiovisual consumption and business models. To do this, the following research questions (RQ) were posed:

\section{RQ1: How do audiences on streaming platforms behave? How is audience quantified and/or weighted? Can we, in this context, continue to consider audience as goods?}

We conclude that, in the context of subscription model streaming, the value of the audience as goods persists, although this has switched from its commercial worth (advertising) to its impact on the platform's body of customers (attraction and retention) and brand popularity. The new model (atawad+ac) involves infinite consumption combinations that are difficult to standardise. In the specific case of Netflix, the audience is weighted or quantified depending on the intended purpose. Internally, content viewing figures are weighted, giving greater importance to new customers who view the content as their first choice and existing customers at risk of cancelling their subscription. In this case, audience is used to assess the efficiency of programmes, as an indicator to evaluate the money invested in content, based on the quality 
and quantity of the audience it has managed to attract. Along with this audience constructed for internal (non-public) use, there is another type of audience, external and cumulative, which the company uses as a publicity strategy and, by extension, a measure of success: the figure quantifies all accounts that 'decided to watch at least two minutes of a programme', a concept similar to television ratings.

\section{RQ2: What aspects should a new, revised concept of audience consider in the context of SVOD? What new audience dimensions does the concept of video consumption on streaming platforms introduce?}

Based on the analysis, we conclude that a revised concept of audience in the context of SVOD should consider a number of aspects:

- It is constructed from an enormous volume of data whose main characteristic is its fragmentation (fragmented audience).

- Audience research in this context involves interpreting and assigning a value to each new audience dimension arising from online consumption (weighted audience) and not just accumulating data.

- The volatility inherent in these platform audiences, jumping easily between content and services -a volatile or 'gaseous' audience, using the term in Callejo-Gallego (2019)-, suggests that weight should be given to what is chosen and the quality of such choices, thereby producing new audience dimensions based on the connection established with content (adhered audience).

Given this revised concept of SVOD audience (fragmented, weighted, volatile and adhered), this study concludes that new dimensions above and beyond data provided by TAMs should be included. Such new dimensions are based on the premise that the value of the audience is not just its size, but also its engagement (users' involvement with content) and its depth of attention (audience density, to use Netflix's term). In assigning value to audience attention, the methodology used by Parrot Analytics, which takes us into the field of big data, opens up an interesting line of research: varying the weighting based on users' level of effort, both internally (frequency, intensity and repeat viewing) and externally (posts on social media, information searches in Google, illegal downloads).

\section{RQ3: Do new audience dimensions require a renewed concept of popularity?}

The conclusion from the case study is that they do. Given the general lack of quantitative data, popularity now has a major qualitative component, a diffuse but evident impact that provides visibility for a programme, involving several subjective elements arising from the special relationship created between user and content, such as engagement and reputation (the key to retaining and attracting customers) and acceptance/applause that ensures the programme is in the conversation (based on the online impact of the content, a concept similar to Parrot Analytics's demand expressions).

\section{RQ4: Can a single concept of audience be applied to all on-demand audiovisual consumption and business} models?

Given that this article focuses on a case study of a specific platform, it does not provide enough data to give a definitive conclusion. However, we can offer some preliminary thoughts. The heterogeneity intrinsic to the business model of these platforms introduces elements that significantly impede the construction of a global, standard concept of audience for all SVOD services. This is due to a number of factors:

- Unlike television channels, there is no level playing field for streaming platforms with regard to consumption and penetration in the home. Market share can produce distortions in comparative rankings, as content is not fully available to all.

- Content life cycle on a streaming platform involves a number of different phases, thereby transforming the concept of success. With regard to a streaming platform's business goal (attracting and retaining customers), the impact of recently released series in term of popularity is greater (giving it a greater capacity to attract new subscribers) than that of catalogue content (which may have little popularity outside the platform while remaining extraordinarily popular among existing customers, making it a tool for retention). On streaming platforms such as Netflix, the most valuable programmes are those viewed first by new subscribers or customers at risk of cancelling their subscription.

- Release dynamics also require a different reading of the data. Block release is more likely to encourage intense, concentrated 'binge' consumption than does weekly distributed release. Calculating total audience or average audience per episode provides very different readings.

- Not all SVOD services embrace this business formula. Subscription models are starting to use hybrid formulas that combine open broadcast with advertising (free video on demand, FVOD), SVOD (without advertising), advertising video on demand (AVOD) and transactional video on demand (TVOD, permitting content to be temporarily rented). The organisational formula produces catalogues of different types and different viewing combinations, with a significant impact on customers' consumption patterns.

On streaming platforms such as Netflix, the most valuable programmes are those viewed first by new subscribers or customers at risk of cancelling their subscription 
These conclusions from the specific case study of Netflix and Money heist open up an interesting line of research for future studies, looking at more platforms and case studies, to help build a new concept of audience in the context of SVOD consumption. Similarly, more studies on this issue will help assess whether the concept can be extrapolated to all the formulas this audiovisual practice might adopt, based on the general research objective used for this specific analysis.

\section{References}

Álvarez-Monzoncillo, José-María (coord.) (2011). La televisión etiquetada: nuevas audiencias, nuevos negocios. Madrid: Ariel; Fundación Telefónica. ISBN: 9788408098706

https://mediaandentertainmentobservatory.files.wordpress.com/2012/04/la_television_etiquetada.pdf

Arrojo, María-José (2010). “Distribución y financiación de formatos audiovisuales en Internet. Nuevas estrategias para rentabilizar los contenidos". Telos, n. 85.

https://telos.fundaciontelefonica.com/archivo/numero085/distribucion-y-financiacion-de-formatos-audiovisuales-eninternet

Ball, Matthew (2019). "Content, cars and comparations in the Streaming Wars". Matthewball.vc, May, 3. https://www.matthewball.vc/all/contentcarscomparisons

Barlovento Comunicación (2019). Análisis televisivo 2019. Barlovento Comunicación.

https://www.barloventocomunicacion.es/wp-content/uploads/2019/12/analisis-televisivo-2019-BarloventoComunicacion-1. $p d f$

Callejo-Gallego, Manuel-Javier (2002). “Globalización y digitalización de las audiencias”. Política y sociedad, v. 39, n. 1, pp. 69-82.

http://revistas.ucm.es/index.php/POSO/article/view/POSO0202130069A/24049

Callejo-Gallego, Manuel-Javier (2019). “Investigación de audiencias: lost in transition”. CIC. Cuadernos de información y comunicación, v. 24, pp. 155-173.

https://doi.org/10.5209/ciyc.64636

Cascajosa-Virino, Concepción (2016). “Buscando al espectador serial desesperadamente: la nueva investigación de audiencias y la serie El ministerio del tiempo". Dígitos. Revista de comunicación digital, n. 2, pp. 53-69.

https://revistadigitos.com/index.php/digitos/article/view/50

Cascacoja-Virino, Concepción (2018). “De la televisión de pago al vídeo bajo demanda. Análisis de la primera temporada de la estrategia de producción original de ficción de Movistar+". Fonseca: journal of communication, n. 17.

https://doi.org/10.14201/fjc2018175774

Castillo-Izquierdo, Jessica (2016). Teoría de programación de radio y televisión. Publicacions de la Universitat Jaume I. ISBN: 9788416356911

http://repositori.uji.es/xmlui/bitstream/handle/10234/162512/s116_impressora.pdf

Clares-Gavilán, Judith (2014). Estructura y políticas públicas ante los nuevos retos de la distribución y consumo digital de contenido audiovisual. Los proyectos de vídeo bajo demanda de cine Filmin y Universciné como estudio de caso. Tesis doctoral. Universitat Ramon Llull.

http://www.tesisenred.net/handle/10803/247706

Clares-Gavilán, Judith; Medina-Cambrón, Alfons (2018). “Desarrollo y asentamiento del vídeo bajo demanda (VOD) en España: el caso de Filmin". El profesional de la información, v. 27, n. 4, pp. 909-920.

https://doi.org/10.3145/epi.2018.jul.19

Clares-Gavilán, Judith; Merino-Álvarez, Cristina; Neira, Elena (2019). La revolución over the top. Del vídeo bajo demanda (VOD) a la televisión por internet. Editorial UOC. ISBN: 9788491803966

Corbella, Joan M. (2010). "La nueva ecología del audiovisual: nuevos actores, viejos y nuevos problemas". Quaderns del CAC, 34, v. 13, n. 1, pp. 37-45.

https://www.cac.cat/sites/default/files/2019-04/Q34_Corbella_ES.pdf

Cunningham, Stuart; Silver, John (2013). Screen distribution and the new King Kongs in the online world. Palgrave Macmillan. ISBN: 9781349459766

Curtin, Michael; Holt, Jennifer; Sanson, Kevin (2014). Distribution revolution: Conversations about the digital future of film and television. University of California Press. ISBN: 9780520283251

De-Durán, Alberto (2014). Investigación de audiencias y planificación de medios. Publicidad y Relaciones Públicas, Universidad Rey Juan Carlos.

http://www.albertodeduran.es/wp-content/uploads/2014/08/3x09-Investigación-de-audiencias-y-planificación-demedios.pdf 
DeFino, Dean J. (2014). The HBO effect. Bloomsbury Academic. ISBN: 9781441180438

Fernández-Manzano, Eva-Patricia; Neira, Elena; Clares-Gavilán, Judith (2016). "Data management in audiovisual business: Netflix as a case study". El profesional de la información, v. 25, n. 4, pp. 568-576.

https://doi.org/10.3145/epi.2016.jul.06

Gallardo-Camacho, Jorge; Sierra-Sánchez, Javier; Lavín, Eva (2019). "The timeshifted viewing cycle of television programmes after their linear broadcast in Spain". Communication \& society, v. 32, n. 2, pp. 29-43.

https://doi.org/10.15581/003.32.2.29-43

Gallego, Francisco (2013). "Social TV analytics: Nuevas métricas para una nueva forma de ver televisión". Index.comunicación, v. 3, n. 1, pp. 13-39.

http://journals.sfu.ca/indexcomunicacion/index.php/indexcomunicacion/article/view/49/56

García-Santamaría, José-Vicente; Barranquero-Carretero, Alejandro; Rosique-Cedillo, Gloria (2017). "El mercado televisivo español del siglo XXI: concentración y precariedad". Observatorio (OBS*), v. 11, n. 3.

http://obs.obercom.pt/index.php/obs/article/view/774

Gillespie, Marie (ed.) (2007). Media audiences. Maidenhead and New York: Open University Press. ISBN: 9780335218820

Gómez-Uribe, Carlos A.; Hunt, Neil (2016). "The Netflix recommender system: Algorithms, business value, and innovation". AMC Transactions on management information systems (TMIS), v. 6, n. 4, article n. 13.

https://doi.org/10.1145/2843948

González-Neira, Ana; Quintas-Froufe, Natalia (2020). "Preferencias televisivas de la audiencia española (2005-2019): programas, formatos y cadenas". Estudios sobre el mensaje periodístico, v. 26, n. 2, pp. 583-595.

https://doi.org/10.5209/esmp.67777

González-Neira, Ana; Quintas-Froufe, Natalia; Gallardo-Camacho, Jorge (2020). "La medición de la audiencia televisiva: desafíos ante las nuevas plataformas de video". Comunicación y sociedad, v. 17, e7284.

https://doi.org/10.32870/cys.v2020.7284

Halpern, Daniel; Quintas-Froufe, Natalia; Fernández-Medina, Francisco (2016). “Interacciones entre la televisión y su audiencia social: hacia una conceptualización comunicacional". El profesional de la información, v. 25, n. 3, pp. 367-375. https://doi.org/10.3145/epi.2016.may.06

Hernández-Pérez, Tony; Rodríguez-Mateos, David (2016). “Medición integral de las audiencias: sobre los cambios en el consumo de información y la necesidad de nuevas métricas en medios digitales". Hipertext.net, n. 14.

http://doi.org/10.2436/20.8050.01.32

Holt, Jennifer; Sanson, Kevin (2013). Connected viewing: Selling, streaming, \& sharing media in the digital age. Routledge. ISBN: 9780415813600

Huertas, Amparo (2002). La audiencia investigada. Gedisa Editorial. ISBN: 8474329574

Huertas, Amparo (2006). "De la medición de la audiencia al conocimiento de los públicos". Portal de la comunicación InCom-UAB. Lecciones del portal.

https://incom.uab.cat/portalcom/wp-content/uploads/2020/01/22_esp.pdf

Huertas, Amparo (2018). "Continuidades y rupturas en la medición de las audiencias". Portal de la comunicación InCom-UAB. Lecciones del portal.

https://incom.uab.cat/portalcom/wp-content/uploads/2020/01/104.pdf

Iglesias, Francisco (1985). "Investigación de audiencias en televisión y mejora de calidad de los contenidos". Documentación de las ciencias de la información, v. 9, pp. 225-233.

https://revistas.ucm.es/index.php/DCIN/article/view/DCIN8585110225A

Jauset, Jordi A. (2014). Estadística para periodistas, publicitarios y comunicadores. Editorial UOC. ISBN: 9788490640982

Keating, Gina (2012). Netflixed: the epic battle for America's eyeballs. Penguin Group. ISBN: 9781101601433

Landau, Neil (2016). TV outside the box: trailblazing in the digital television revolution. Focal Press. ISBN: 978113863936

Lobato, Ramón (2019). Netflix nations. Netflix the geography of digital distribution. New York University Press. ISBN: 978 1479841516

Lotz, Amanda D. (2014). The television will be revolutionized, $2^{\text {nd }}$ ed. New York University Press. ISBN: 9781479865253

Lotz, Amanda D. (2018). We now disrupt this broadcast: how cable transformed television and the Internet revolutionized it all. The MIT Press. ISBN: 9780262037679 
Masip, Pere; Ruiz-Caballero, Carlos; Suau, Jaume (2019). "Active audiences and social discussion on the digital public sphere. Review article". El profesional de la información, v. 28, n. 2, e280204.

https://doi.org//10.3145/epi.2019.mar.04

McQuail, Dennis (1992). Media performance: Mass communication and the public interest. SGAE publications Ltd. ISBN: 9780803982956

Morley, David (2003). Television, audiences and cultural studies. Routledge. ISBN: 9780415054454

Napoli, Philip M. (2008). "Toward the model of audience evolution: New technologies and the transformation of the media audiences". McGannon Center working paper series. Paper 15.

http://fordham.bepress.com/mcgannon_working_papers/15

Napoli, Philip M. (2012). "Audience evolution and the future of audience research". The international journal of media management, v. 14, n. 2, p. 79-97.

https://doi.org/10.1080/14241277.2012.675753

Napoli, Philip M. (2016). "Special issue introduction: Big data and media management". International journal on media management, v. 18, n. 1, pp. 1-7.

https://doi.org/10.1080/14241277.2016.1185888

Neira, Elena (2015). La otra pantalla. Redes sociales, móviles y la nueva televisión. Barcelona: UOC. ISBN: 97884 91161165

Neira, Elena (2020). Streaming wars. La nueva televisión. Libros Cúpula. ISBN: 9788448026585

Neira, Elena; Clares-Gavilán, Judith; Sánchez-Navarro, Jordi (2020). “Impacto de los servicios OTT en la generación de comunidades de gustos y nichos globales: Netflix como estudio de caso". Comunicació. Revista de recerca i d'anàlisi, v. 37, n. 2.

https://doi.org/10.2436/20.3008.01.198

Netflix investors (2018). “Letter to shareholders. Final Q1 2018”. Netflix, January 21. https://s22.q4cdn.com/959853165/files/doc_financials/quarterly_reports/2018/q1/FINAL-Q1-18-Shareholder-Letter.pdf Netflix investors (2020a). “Letter to shareholders. Final Q4 2019”. Netflix, April 16. https://s22.q4cdn.com/959853165/files/doc_financials/2019/q4/FINAL-Q4-19-Shareholder-Letter.pdf

Netflix investors (2020b). “Letter to shareholders. Final Q1 2020”. Netflix, April 21. https://s22.q4cdn.com/959853165/files/doc_financials/2020/q1/FINAL-Q1-20-Shareholder-Letter.pdf

Núñez-Ladevéze, Luis; Torrecillas-Lacave, Teresa; Irisarri-Núñez, José-Antonio (2019). “Audiencias y redes: pautas de consumo de industria cultural en España". Estudios sobre el mensaje periodístico, v. 25, n. 1, pp. 421-441.

https://doi.org/10.5209/ESMP.63738

Pacheco-Pailahual, Stephanie (2017). “Luis A. Albornoz; María-Trinidad Leiva (eds.). Diversidad e industria audiovisual: el desafío cultural del siglo XXI". CIC. Cuadernos de información y comunicación, v. 22, pp. 315-345. https://doi.org/10.5209/CIYC.55985

Papí-Gálvez, Natalia; Perlado-Lamo-de-Espinosa, Marta (2018). “Investigación de audiencias en las sociedades digitales: su medición desde la publicidad”. El profesional de la información, v. 27, n. 2, pp. 383-393.

https://doi.org/10.3145/epi.2018.mar.17

Portilla, Idoia (2015). "Television audience measurement: proposals of the industry in the era of digitalization". Trípodos, n. 36, pp. 75-92.

http://www.tripodos.com/index.php/Facultat_Comunicacio_Blanquerna/article/view/243

Portilla, Idoia; Vara-Miguel, Alfonso; Díaz-Espina, Carolina (2016). “Innovación, modelos de negocio y medios de audiencias ante los nuevos retos del mercado de la comunicación” En: Sábada-Chalezquer, Charo; García-Avilés, José-Alberto; Martínez-Costa, María-del-Pilar. Innovación y desarrollo de los cibermedios en España. Universidad de Navarra. Eunsa, pp. 31-39. ISBN: 9788431331252

Quintas-Froufe, Natalia; González-Neira, Ana (2016). “Consumo televisivo y su medición en España: camino hacia las audiencias híbridas". El profesional de la información, v. 25, n. 3, pp. 376-383.

https://doi.org/10.3145/epi.2016.may.07

Rodríguez-Mateos, David; Hernández-Pérez, Tony (2015). “Televisión social en series de ficción y nuevos roles del documentalista audiovisual: el caso de El ministerio del tiempo". Index comunicación, v. 5, n. 3, pp. 95-120.

https://journals.sfu.ca/indexcomunicacion/index.php/indexcomunicacion/article/view/200 
Roel, Marta (2019). "Aproximación al estudio del consumo televisivo en el ecosistema audiovisual digital español: de la audiencia audimétrica a la audiencia poliédrica". Estudios sobre el mensaje periodístico, v. 25, n. 1, pp. 477-492.

https://doi.org/10.5209/ESMP.63741

Roettgers, Janko (2019). "Why Netflix will keep breaking hearts and cancelling shows". Variety, Mar 20.

https://variety.com/2019/digital/news/netflix-show-cancellations-metrics-business-1203167540

Roncallo-Dow, Sergio (2017). "Introducing three dimensions of audience fragmentation". Signo y pensamiento, v. 36, n. 70, pp. 74-90.

https://doi.org/10.11144/Javeriana.syp36-70.idaf

Smith, Michael D.; Telang, Rahul (2016). Streaming, sharing, stealing. Big data and the future of entertainment. The MIT Press. ISBN: 9780262034791

Toonkel, Jessica; Dotan, Tom; Shah, Beejoli (2019). "Netflix plays new role: budget-concious”. The information, July 1. https://www.theinformation.com/articles/netflix-plays-new-role-budget-conscious

Tryon, Chuck (2013). Reinventing cinema and on-demand culture. Rutgers University Press. ISBN: 9780813561097

UK Parliament (2019). Netflix supplementary written evidence. Communications and Digital Committee.

http://data.parliament.uk/writtenevidence/committeeevidence.svc/evidencedocument/communications-and-digitalcommittee/public-service-broadcasting-in-the-age-of-video-on-demand/written/104558.html

Vacas-Berdanyes, Ricardo (2012). "Pantallas y audiencias en mestizaje”. Capçalera, v. 3, pp. 32-35.

Vázquez-Herrero, Jorge; González-Neira, Ana; Quintas-Froufe, Natalia (2019). “La audiencia activa en la ficción transmedia: plataformas, interactividad y medición". Revista latina de comunicación social, v. 74, pp. 73-93.

http://doi.org/10.4185/RLCS-2019-1322

Webster, James G. (2014). The marketplace of attention: How audiences take shape in a digital age. Cambridge, MA: The MIT Press. ISBN: 9780262529891

Yin, Robert K. (2009). Case study research. Design and methods. Thousand Oaks: Sage. ISBN: 9781412960991

\section{Interviews}

Moreno, Jesús. Director of product design and business development at Atresmedia Digital (25/03/2019).

Rojas, Alejandro. Director of applied analytics at Parrot Analytics (07/04/2020).

Sierra Hernando, Francisco. Director of digital content and social media at Atresmedia Televisión (25/03/2019).

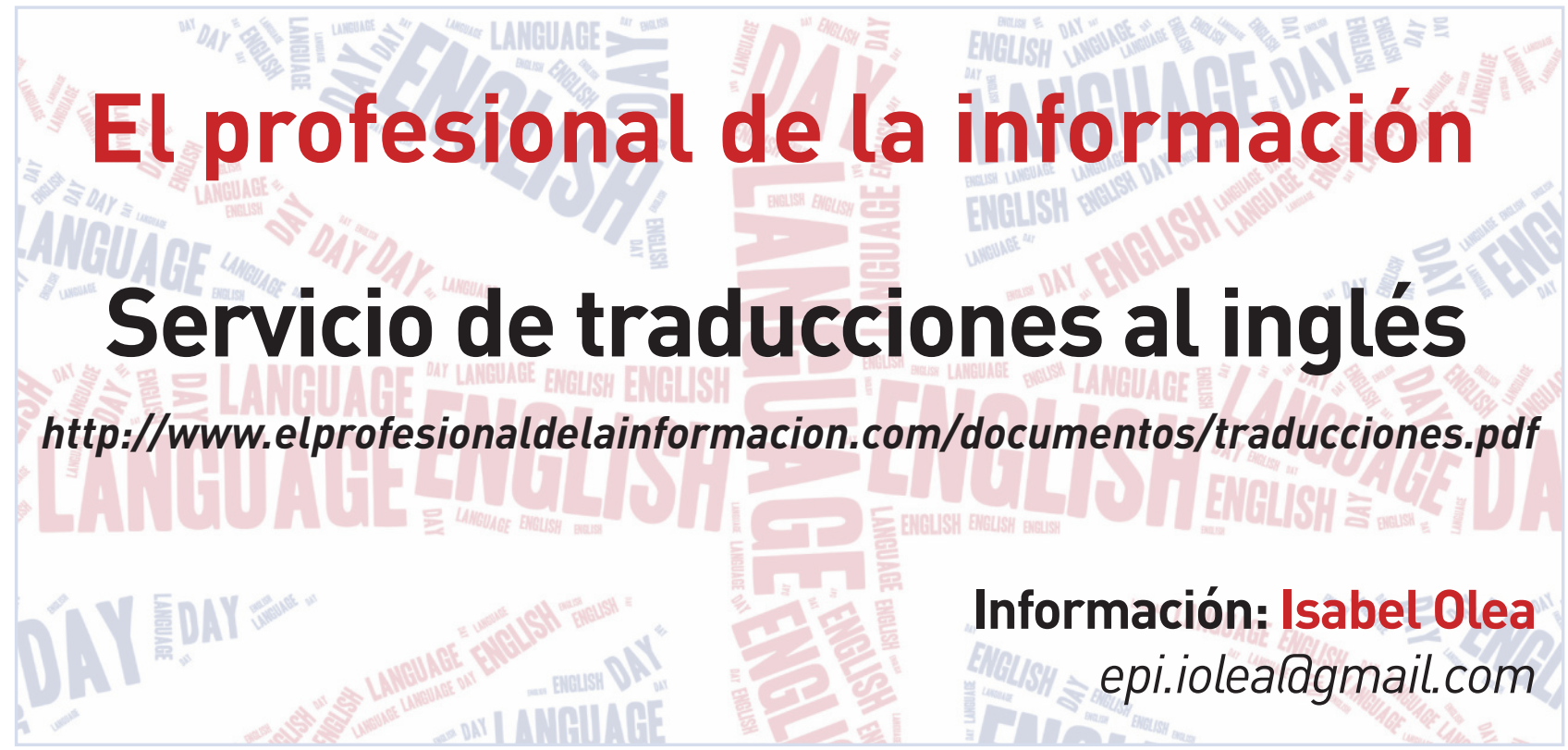

